\title{
A New Social Contract
}

\author{
Ruth A. Shapiro
}

For those of us working and living in Asia, we have witnessed breathtaking change over the past 30 years. New York City has developed since 1987, too, but nothing compared to the dramatic change in Shanghai or Singapore during the same time period. Easiest to see are the new roads, airports, trains and the buildings, especially the buildings. In 1996, according to the mayor, one in five active construction cranes in the world were in Shanghai. But people are also changing. Asians are part of a global marketplace and cultural community like never before, particularly those in big cities. Connectivity has leapt forward at a blazing pace. From 2015 to 2016 alone, the number of active Internet users jumped 12 percent, and the figure for those with smart phones went up by 21 percent in Asia. ${ }^{1}$ There are also extraordinary improvements in education, life expectancy, and other quality of life indicators.

The news, however, is not all good. The Gini coefficient, a measure of the gap between the rich and the poor, is growing around the world. In Asia, this is happening at an accelerated pace. In many respects China is the first superpower to still be a developing country. While one can marvel at the modernity of Asia's cities, there remains great poverty in both urban and rural areas. The dichotomy - between rich and poor, urban and rural, those plugged into the global economy and those very much left out-is glaringly obvious when travelling around many parts of Asia. Some coun-

\footnotetext{
R.A. Shapiro

CAPS, Hong Kong SAR, China
}

(C) The Author(s) 2018

R.A. Shapiro et al., Pragmatic Philanthropy, https://doi.org/10.1007/978-981-10-7119-5_9 
tries have moved into first-world status, including South Korea, Japan, Taiwan, and Singapore, but for the others, the need to deal with a bifurcated set of needs remains a significant challenge.

We have explored in these pages how governments, philanthropists, and nonprofit leaders endeavor to cope with rapid change. The chapter on legal and regulatory reform showcases the various attempts by governments throughout the region to react to new challenges. In fact, much of the legal reform is reactive and thus will undoubtedly bring new and unforeseen problems in the attempts to deal with current problems. The state of regulatory flux will continue as policies are drawn up and tested.

While the economic development of Asia has sped along, many aspects of work and play retain traditional qualities. Throughout this book, we have emphasized the importance of relationships in philanthropic decisionmaking, social delivery organization (SDO) success, and in the partnerships that often form to address a challenge. However much we hear that relationships matter in Asia, it is a deep truth in the field of charitable work, as the book aims to illustrate. Those who truly succeed in Asia-whether they are in government, in business, or running an SDO-have created, nurtured, and utilized networks and a whole web of relationships.

In our chapter on relationships, we detail the importance they play in the trajectory of an SDO. Relationships bring credibility to CARD in the Philippines. They bring the potential to raise funds for the China Medical Foundation in Hong Kong. They bring expertise to Mercy Malaysia, and they bring the second and third circles of networks for many organizations. Though this is also the case elsewhere in the world, relationships take on much greater significance in environments where skills are in short supply.

For philanthropists, relationships are often the only means by which one can conduct due diligence. The existence of the trust deficit in Asia means that organizations may be viewed with suspicion until proven otherwise, and the involvement of a friend or business partner in an organization provides assurance of credibility and reliability.

Projects championed by government officials gain further currency for donors interested in enhancing guanxi, or beneficial relationships. In fact, when I mention that the return on investment for philanthropy is increased guanxi to donors, their reaction is most often confirmation. This is not always the case when making philanthropic decisions, but it is certainly prevalent.

As noted in Chapter 2, there is a long history of charitable giving in Asia, but for the most part, the systems that come from organized philanthropy are nascent. In that context, relationships are how one gets some- 
thing done. It means enlisting the support of someone who can help to accomplish a particular task for a project. We found an example in the mere collection of data for our recent study on enabling environments for philanthropy. Personal networks were essential in getting people to fill out our surveys. Our contacts reached out to theirs and developed guanxi as result, strengthening their ties with us and with those they contacted. Both sides appreciated their input, and their roles as interlocutors reinforced the value of their relationships.

While relationships have long been useful, technology is providing new ways of getting things done. Asia has embraced technology along with development. Nine of the top 20 most connected countries in the world are in Asia. ${ }^{2}$ Technology has a profound impact on many aspects of social and economic development in the region. In the charitable sector, it changes approaches to business in four important ways: through fundraising, transparency, accountability, and impact.

Crowdfunding is a phenomenon around the world, and in a region as connected as Asia it is becoming a powerful tool. One of the most cited examples is the story of Deng Fei in China and the free lunch program he started. Concerned about hungry kids, Deng Fei asked for support online in 2011 to provide school lunches to kids in poor areas. Within a month, his posting on Weibo (China's Twitter equivalent) generated more than RMB I million (US\$150,000) in small amounts from numerous donors. By the end of 2016, 80,000 children received lunch daily and the government picked up the program to expand it in five provinces.

Technology also enables greater transparency and accountability in two important ways. First, in many Asian countries, online listings include organizations adhering to stricter reporting standards. The Hong Kong Council for Social Services' WiseGiving platform, for example, allows potential donors to find out a great deal of information about the 450 SDOs on their site. The Philippine Council for NGO Certification lists all those certified on its website. There are other such sites in India, Japan, South Korea and China.

The second way that technology makes a difference is as an important watchdog tool. While governments might not have the wherewithal to patrol the sector, millions of eyes look at nonprofit projects every day. The Guo Meimei/Red Cross incident became a scandal when her post of lavish spending went viral. So did a video of a rat at the buffet table of one of Malaysia's largest public hospitals. Needless to say, the kitchens there are much better maintained now! Everyone with a smart phone becomes an investigative journalist and whistleblower. This powerful trend can bring about better governance and oversight. 
Technology even helps with impact. Many organizations use technology as an integral part of their offerings. In this book, we saw organizations as diverse as Akademi Berbagi in Indonesia and Tree Planet in South Korea use the Internet to communicate and as their distribution system. They also illustrate the circular aspect of using technology well. When an organization fundraises successfully online, it can then scale up its projects and report the increased impact, which assists in further fundraising and so on. We picked the 30 organizations in our studies because they were particularly successful. All of them spent time and resources developing their Internet presences, without which it would be more difficult to be successful today.

Another important recent trend in Asia drawing on relationships and technology is the wave of young people who see addressing social challenges as a viable career option. This is new. In the chapter on philanthropists, we cited the historical tendency for the best and the brightest to go into lucrative careers, a phenomenon contributing to the trust deficit hurdle of charitable organizations. Such narrow career choices made sense when Asia was just coming out of widespread poverty. Now, more and more young people want to work with SDOs, with philanthropic foundations, in social enterprises and impact investing. There is energy and enthusiasm for using business to achieve social good, and while these social enterprises have not made significant difference to date, it is still early days and many are moving into this sector. No doubt, scalable social innovations will proliferate and present us with solutions that haven't been available before.

Certain innovations skip past steps followed in the West. We can see how cell phone coverage, for example, arrived in Asia before the full distribution of land lines. With an incomplete network of telephone lines, mobile technologies were able to "leap-frog" to massive scale quite quickly. The dearth of landline infrastructure was not just about the hardware but the environment as well. While it is true that there were fewer phone lines in place, there were also fewer stakeholders with their own agendas to deal with. In the United States, the pre-existing phone companies put up road blocks to cell phones as they were slow to realize how critically important this technology was going to be. Similarly, in China, banks leapt past the use of paper checks. Once people became wealthy enough to substantially increase their regular purchases, transactions went digital to a degree surpassing the West. In 2016, mobile payments in China were 50 times those in America. 
In the charitable sector, we find similar factors in place. Throughout Asia, human and organizational infrastructures are sparser and newer. This means that if we find better models, best practices, enabling regulations, and policies, they can be put in place now, allowing Asia to maximize the way that private social investment is made, and to apply it in ways that leverage it much more effectively. It is also true that without established agendas, we have an opportunity to really start with fresh ideas and innovative models.

To see what is possible in the charitable sector, we can look to the "green revolution," the widespread adoption of new seeds and agricultural processes in the 1960s that dramatically increased production worldwide, especially in developing countries, allowing millions to receive better food and nutrition. The green revolution succeeded through five complementary factors: application of new technology, an enabling environment (especially through improved fertilizer and irrigation), the training of an energized cohort of young people in new techniques, sufficient funding, and solid relationships with governments.

All these factors apply now to the charitable sector. In this case, the "technology" consists of the application of better models and best practices as well as the use of the Internet and mobile applications. The enabling environment comes through the popularity of engagement and "giving back" now becoming increasingly popular in Asia. This is important as it is much more organic, more natural. And although there was one unfortunate outcome of the green revolution with the deleterious environmental impact of the same fertilizers that dramatically and somewhat unnaturally increased yield, there is no doubt that much more good took place. The training of young people is also happening apace, at the university level through classes on nonprofit management, philanthropy, corporate social responsibility, and through incubators and hubs for social enterprises. Governments have set up funds for the creation of social enterprises and for other types of social projects, including trainings, workshops, and mentoring of those who receive the funds. On the funding side, while the numbers are difficult to pin down exactly, there is ample evidence of a fast-growing philanthropic movement in Asia.

Which brings us to the last factor: solid relationships with government. As we have discussed throughout this book, this is an area where Asia differs dramatically from the West. There is a social contract in place in Asia. Donors tend to fund projects, programs, and social needs that are aligned with the government's goals in their country, and many successful SDOs do the same. This is true throughout the region. Sometimes this cooperation is explicit. For example, in China, where the new charity law limits the work of SDOs to poverty relief, care for the elderly and orphans, disaster 
relief, education, science, culture, and sports-all issues the government has prioritized for itself as well. In most cases, the understanding is implicit. There is some degree of self-policing in which donors choose to fund programs that comply with government priorities without being told to do so.

There are ramifications in having this social contract. One important one is that when government is involved with an effort to address a social challenge, the idea or innovation can be picked up by the government and scaled in a way that would have been impossible if only the SDO were administering it. Scale is a term that receives much fanfare in the social investment community today. Scale and systemic change are not the same thing. Scale means significantly increasing the number of products or services. Systemic change refers to addressing the causes of the problem and changing the system so that it does not occur again or at least with the same frequency. To achieve great scale and carry out systemic change, you need the government to be involved. The good news in Asia is that in most cases, the government is already involved. What does not happen often enough is that the government is nimble or honest enough to see a solution and then change direction to accommodate it. It is for this reason that some philanthropists, such as the Azim Premji Foundation and Tata Trusts in India, and Wash SyCip and the Jon Ramon Aboitiz Foundation in the Philippines, have begun to train government officials on how to be better at their jobs so that they can more readily put in place viable solutions.

Another benefit of the social contract is the degree to which it brings about societal harmony within a country. Harmony is a prized value and outcome in the region. It is integral to the "Asian way" prescribed by Prime Ministers Mahathir and Lee Kuan Yew. It is also a way to mitigate critique and maintain social cohesion. The new laws in India, China, and Indonesia seem to push in this direction. In a much-cited article, Harvard University professors Roberto Foa and Yascha Mounk argue that based on public opinion polling, young people, especially those in developed countries, are not satisfied with their governments and are open to alternatives, including benevolent authoritarian regimes. ${ }^{3}$

In Asia, most have not known any other kind of governance. We are at a pivotal juncture. It is possible that with more government curbs on nonprofits engaging in advocacy-combined with the trend labeled in this book as "DIY philanthropy," when companies take on addressing social challenges on their own and do not work with and through nonprofit organizations-those organizations will starve. We could witness the withering away of those parts of civil society acting as contrarian voices, 
while at the same time improving the social indicators and certain aspects of the quality of life for many.

On the other hand, with other new trends-including use of the Internet and social media, and the outpouring of support to address social challenges from the region's youth-we could see an activation of civil engagement unparalleled in Asian history.

Throughout Asia, the seesaw dynamism between old and new influences societal evolution in new and interesting ways. There is considerable variation across the region, but the presumption that every country would take on the attributes of the developed Western world has been debunked. Asia is evolving with unique characteristics that differentiate it from the West.

In Chapter 1, we proposed to answer the following questions:

- Is there an "Asian" way of doing good? If there is, why so, and what are the implications?

- What is the Asian philanthropy and social delivery ecosystem, and how has it evolved?

- What are the characteristics and strategies of successful Asian SDOs?

- Why is it important to distinguish between SDOs and other types of nonprofit organizations?

- What are trends of Asian philanthropists and why?

- What are shared challenges for the region?

- What can donors, SDO policymakers, and the public at large do to enable the social sector to thrive and contribute to improving the lives of people throughout the region?

Only the last has not been sufficiently answered. In order to do so, we must ask ourselves fundamental questions about the world we want to live in and what values are important to us. Many say that we are living in the Asian century. Time will tell what the implications of that truly are.

Asia has grown into the most dynamic economic region in the world today. Change is happening with great dispatch. Until recently, there has not been much infrastructure around the charitable sector, a condition improving rapidly along with the expanding reach of philanthropic efforts. These charitable aims grow through long-standing traditions, including the importance of relationships and an interest in family, as well as through newer developments, like the leveraging of technology and governmental partnerships. While the region retains its challenges, many will be met through the increased means and desire for doing good. 


\section{Notes}

1. Kemp, Simon. "Digital in 2016: Data, Trends and Insights." Tech in Asia. February 22, 2016. https://www.techinasia.com/talk/digital-2016-datatrends-insights. Accessed July 30, 2017.

2. Global Internet Report 2016. The Internet Society. http://www.internetworldstats.com/top20.htm. Accessed July 30, 2017.

3. Foa, Roberto Stephan and Yascha Mounk. "The Danger of Deconsolidation: The Democratic Disconnect.” Journal of Democracy, 27.3 (July 2016).

Open Access This chapter is licensed under the terms of the Creative Commons Attribution 4.0 International License (http://creativecommons.org/licenses/ by $/ 4.0 /$ ), which permits use, sharing, adaptation, distribution, and reproduction in any medium or format, as long as you give appropriate credit to the original author(s) and the source, provide a link to the Creative Commons license and indicate if changes were made.

The images or other third party material in this chapter are included in the chapter's Creative Commons license, unless indicated otherwise in a credit line to the material. If material is not included in the chapter's Creative Commons license and your intended use is not permitted by statutory regulation or exceeds the permitted use, you will need to obtain permission directly from the copyright holder.

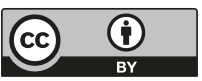

